\title{
ANALISIS TEORITIK MODEL PEMBANGUNAN DAERAH (DESA) TERTINGGAL
}

\author{
Oleh : SYAMSURI
}

\begin{abstract}
ABSTRAK :
Daerah tertinggal merupakan suatu daerah yang tingkat pembangunan dan kesejahteraan rakyatnya tertinggal atau kurang berkembang dari daerah lain. Dengan berbagai persoalan yang dialami oleh daerah tertinggal, diantaranya terbatasnya sumberdaya alam, rendahnya sumberdaya manusia, sangat terbatasnya prasarana dan sarana seperti sarana transportasi, komunikasi, kesehatan, pendidikan, dan pelayanan lainnya serta kemiskinan, maka dibutuhkan suatu model kebijakan/program pembangunan yang diarahkan untuk melakukan percepatan pembangunan di daerah tertinggal. Model yang dimaksud disesuaikan dengan karakteristik, potensi dan persoalan yang dialami oleh daerah tersebut. Tujuan dari penulisan ini adalah untuk menambah khasanah teoritik dalam melakukan kajian tentang pembangunan daerah (desa) tertinggal.
\end{abstract}

\section{Kata Kunci : Pembangunan Desa, Model Pembangunan Desa, dan Daerah Tertinggal.}

\section{Pendahuluan}

Secara nasional bahwa meningkatnya pembangunan ekonomi selama ini masih belum mampu meningkatkan kesejahteraan rakyat secara meluas dan merata, indikator utamanya adalah masih tingginya tingkat kesenjangan dan kemiskinan (Suharto, 2008), terutama antara daerah perkotaan dengan perdesaan. Hal ini disebabkan adanya ketidakmerataan dan ketidakadilan dalam distribusi pembangunan, karena kebijakan pembangunan yang dilakukan selama ini lebih mengutamakan pembangunan di daerah perkotaan dan dipusat-pusat pemerintahan sedangkan di daerah perdesaan kurang mendapat perhatian yang serius, sehingga terjadi kesenjangan pembangunan antara daerah perkotaan dan perdesaan yang menyebabkan tingginya angka kemiskinan di daerah perdesaan (Joshi dan Gebremedhin, 2012). Disisi lain ada dua alasan mengapa permasalahan pembangunan desa masih relevan dibahas, pertama kendati dalam dua dasawarsa terakhir perkembangan kota semakin maju tetapi perkembangan perdesaan justru sebaliknya, sedangkan wilayah negara didominasi oleh daerah perdesaan; dan Kedua kendati sejak tahun 1970-an pemerintah Orde baru mencanangkan berbagai macam kebijaksanaan dan program pembangunan perdesaan, secara umum kondisi sosial ekonomi desa masih memperhatikan dan persoalan kemiskinan dan kesenjangan menjadi masalah krusial di perdesaan. Kemiskinan dan kesenjangan dalam pembangunan membuat daerah tersebut menjadi tertinggal (Suryono, 2010).

\section{Pengertian dan Karakteristik Desa}

Secara historis desa merupakan cikal bakal terbentuknya masyarakat dan pemerintahan (di Indonesia) jauh sebelum bangsa ini merdeka. Struktur sosial sejenis desa, masyarakat adat dan lain sebagainya telah menjadi institusi sosial yang mempunyai posisi yang sangat strategis dalam pembangunan bangsa. Desa merupakan institusi yang otonomi dengan tradisi, adat-istiadat dan relatif mandiri. Hal ini ditunjukan dengan tingkat keragaman yang tinggi membuat desa mungkin merupakan wujud dari suatu bangsa.

Istilah desa berasal dari bahasa India — swadesi\| yang berarti tempat asal, tempat tinggal, negeri asal atau tanah leluhur yang merujuk pada satu kesatuan hidup dengan kesatuan norma serta Perencanaan Desa Terpadu memiliki batas yang jelas (Yayuk dan Mangku, 2003). Istilah desa dan perdesaan sering dikaitkan dengan pengertian rural dan village yang dibandingkan dengan kota (city/town) dan perkotaan (urban). Konsep perdesaan dan perkotaan mengacu kepada karakteristik 
masyarakat sedangkan desa dan kota merujuk pada suatu satuan wilayah administrasi atau teritorial, dalam hal ini perdesaan mencakup beberapa desa (Tarigan, 2003). Sedangkan Di Indonesia penggunaan istilah tersebut digunakan dengan cara yang berbeda untuk masing-masing daerah, misalnya dusun bagi masyarakat Sumatera Selatan, dati bagi Maluku, kuta untuk Batak, nagari untuk Sumatera Barat, atau wanua di Minahasa. Bagi masyarakat lain istilah desa memiliki keunikan tersendiri dan berkaitan erat dengan mata pencahararian, norma dan adat istiadat yang berlaku (Sumpeno, 2011:3).

Dalam kamus bahasa Indonesia, yang dimaksud dengan desa adalah 1) suatu sekelompok rumah diluar kota yang merupakan kesatuan, kampung (di luar kota) atau dusun; 2) dusun atau udik (dalam arti daerah pedalaman sebagai lawan dari kota (Poerwadarminta, 1976). Sedangkan menurut Landis yang dikutip oleh Ahmadi (2003) menyatakan bahwa desa adalah suatu wilayah yang pendudunya kurang dari 2500 jiwa. Dengan ciri-ciri sebagai berikut: (a) mempunyai pergaulan hidup yang saling kenal mengenal antara ribuan jiwa; (b) ada pertalian perasaan yang sama tentang kesukaan terhadap kebiasaan; (c) cara berusaha (ekonomi) adalah agraris yang sangat dipengaruhi alam, seperti: iklim, keadaan alam, kekayaan alam, sedangkan pekerjaan yang bukan agraris adalah bersifat sambilan (Yansen, 2013:95).

Dalam UU Nomor 32 Tahun 2004 pasal 1 ayat 12 tentang Pemerintahan Daerah disebutkan Desa atau yang disebut dengan nama lain, selanjutnya disebut desa, adalah kesatuan masyarakat hukum yang memiliki batas batas wilayah yang berwenang untuk mengatur dan mengurus kepentingan masyarakat setempat, berdasarkan asal-asul dan adat istiadat setempat yang diakui dan dihormati dalam sistem Pemerintahan Negara Kesatuan Republik Indonesia. Secara administratif istilah desa di Indonesia adalah pembagian wilayah administratif yang di bawah kecamatan, yang dipimpin oleh Kepala Desa. Sejalan dengan undang-undang di atas Widjaja (2005:3) mendefinisikan desa sebagai kesatuan masyarakat hukum yang mempunyai susunan asli berdasarkan hak asal-usul yang bersifat istimewa. Landasan pemikiran mengenai Pemerintahan Desa adalah keanekaragaman, partisipasi, otonomi asli, demokratisasi dan pemberdayaan masyarakat.

Dari beberapa pengertian di atas dapat tarik benang merahnya adalah bahwa desa merupakan Self Community yaitu komunitas yang mengatur dirinya sendiri. Dengan pemahaman bahwa desa memiliki kewenangan untuk mengurus dan mengatur kepentingan masyarakatnya sesuai dengan kondisi dan sosial budaya setempat, maka posisi desa yang memiliki otonomi asli sangat strategis sehingga memerlukan perhatian yang seimbang terhadap penyelenggaraan otonomi daerah. Karena dengan otonomi desa yang kuat akan mempengaruhi secara signifikan perwujudan otonomi daerah. Sebagai daerah otonom, maka desa memiliki wewenang : 1) menyelenggarakan urusan pemerintahan yang sudah ada berdasarkan hak asal-usul desa; 2) menyelenggarakan urusan pemerintahan yang menjadi kewenangan kabupaten/ kota yang diserahkan pengaturannya kepada desa, yakni urusan pemerintahan yang secara langsung dapat meningkatkan pelayanan masyarakat;

3) tugas pembantuan dari pemerintah, Pemerintah Provinsi, dan Pemerintah Kabupaten/Kota; dan 4) urusan pemerintahan lainnya yang oleh peraturan perundang-undangan diserahkan kepada desa (PP. No 72 Tahun 2005 Bab III Pasal 7 tentang Desa)

Dengan demikian bahwa desa merupakan suatu wilayah yang ditempati oleh jumlah jiwa yang relatif kecil tetap memegang teguh nilai-nilai dan adat-istiadatnya yang khas. Dalam tatanan bengsa dapat dikatakan bahwa desa merupakan wilayah terkecil atau pemerintah negara paling bawah yang otonom dengan asal-usul dan adat istiadat yang diakui dan dilindungi oleh negara. Desa merupakan bagian vital bagi keberadaan bangsa ini. Disebut vital karena desa merupakan satuan terkecil dari bangsa ini yang menunjukkan keragaman bangsa. Selama ini terbukti keragaman tersebut telah menjadi kekuatan penyokong bagi tegak dan eksisnya bangsa. Dengan demikian penguatan desa menjadi hal yang tidak bisa ditawar dan tidak bisa dipisahkan dari pembangunan bangsa secara menyeluruh.

Setiap desa memiliki kekhasan tersendiri dan kekhasan tersebut yang menjadikan desa itu bisa berbeda-beda dalam kehidupan kesehariannya, perbedaan itu nampak terihat dalam perilaku sosial 
keseharian mereka. Pada situasi dan kondisi tertentu, sebagian karakteristik dapat digeneralisasikan pada kehidupan masyarakat, misalnya masyarakat Jawa, Batak, Banjar, Bugis Dayak dan lainlainnya. Namun demikian, dengan adanya perubahan sosial religius dan perkembangan ilmu pengetahuan, informasi dan teknologi, terkadang sebagian karakteristik tersebut sudah tidak begitu nampak dan bahkan tidak berlaku. Untuk itu Yansen (2010) menyatakan ada beberapa karakteristik masyarakat desa, yang terkait dengan etika dan budaya mereka, yang bersifat umum yang selama ini masih sering ditemui, yaitu: Sebagian besar masyarakat desa hidup dalam kesederhanaan, Masyarakatnya mudah menaruh curiga terhadap orang baru yang belum mereka kenal, masyarakatnya sangat menjunjung tinggi adat dan kesopanan, sangat tingginya rasa suasana kekeluargaan dan persaudaraan, cendrung berbicara apa adanya, cendurung minder dan tidak banyak omong terhadap orang kita, menghargai orang lain dan berusaha membalas budi dengan orang yang bernah berbuat bagi kepada mereka, Jika berjanji, akan selalu diingat dan ditepati, Suka bergotong-royong, Demokratis, Masyarakat perdesaan dikenal sangat religious dan suka mengaktualisasi diri ke dalam kegiatan budaya yang bernuansa keagamaan, misalnya: tahlilan, rajaban, Jumat Kliwonan, dan lainlain.

Kemudian Adisasmita (2006:100) membuat karakteristk desa berdasarkan tipologi desa, tipologi desa berdasarkan topografis dapat dibagi menjadi empat, yakni 1) desa daerah pegunungan, merupakan suatu desa yang berada di daerah pegunungan; 2) desa dataran tinggi, merupakan desa yang berada di daerah dataran tinggi tetapi tidak di daerah pegunungan; 3) desa dataran rendah, merupakan desa yang berada di daerah yang tidak berada pinggiran sungai/pantai; sedangkan 4) desa pasisir/desa pantai, desa ini biasanya berada di sekitar pantai atau bisa juga berada di daerah aliran sungai.

Masyarakat desa umumnya hidup dalam situasi sederhana dengan mata pencaharian sangat tergantung dari kondisi geografis wilayahnya, misalnya usaha tani, nelayan, ternak, kerajinan tangan dan pedagang kecil dan banyak mengandalkan produksi pertanian masyarakat terutama untuk memenuhi keperluan sendiri (subsistence). Masyarakat desa dalam kehidupan sehari-hari masih memegang teguh tradisi, nilai-nilai dan adat istiadat secara turun temurun. Bukan berarti tradisi dan adat istiadat yang dianut tidak menunjang usaha pembangunan, sebagian justru dibutuhkan untuk memelihara kelangsungan hidup dan lingkungan. Walaupun secara psikologis masyarakat desa cenderung memiliki sifat konservatif dan ortodoks, fatalis dan suka curiga terhadap orang luar, namun demikian, masyarakat desa dapat bersikap hemat, cermat dan menghormati orang lain yang terkadang sulit ditemukan di perkotaan (Sumpeno, 2011).

\section{Tipologi Desa}

Berdasarkan data dari BPS tahun 2011 secara nasional bahwa jumlah desa di Indonesia berjumlah 78.198, masing-masing desa mempunyai karakteristik yang berbeda. Karakteristik dan kekakhasan desa itu tidak terlepas dari kondisi desa itu sendiri. Dengan variasinya yang sangat luas, maka sangat sulit untuk merumuskan dan menentukan strategi pembangunan yang akan dilakukan. Untuk mencari solusi tersebut dipandang perlu untuk menyusun tipologi desa. Dengan tipologi desa yang ditetapkan akan diperoleh gambaran yang lebih sederhana dan dapat menggambarkan profil dan ciri desa, dengan demikian akan memudahkan dalam menganalisanya dan menyusun strategi kebijakan pembangunan. Tipologi menggambarkan tipe atau pola, ataupun sebagai pencerminan model berdasarkan kemiripan atau keserupaan ciri-ciri dan potensi dan kondisi sumberdaya (alam, manusia dan buatan) yang dimiliki oleh suatu desa, atau dikaitkan dengan aspek topografinya, kegiatan ekonomi daerah yang dominan, kemampuan keswadayaan masyarakat, dan lainnya (Adisasmita, 2013:110)

Berdasarkan karakteristik desa yang ada, maka Adisasmita (2013) merumuskan berbagai macam tipologi desa, diantaranya:

1) Tipologi desa berdasarkan aspek topografi, terdiri dari desa daerah pegunungan, desa dataran tinggi desa dataran rendah dan desa pasisir/pantai. 
2) Tipologi desa berdasarkan kemampuan keswadayaan, terdiri dari:

a) desa swadaya (tradisional), pada umumnya masyarakatnya masih bersifat tradisional dalam arti bahwa sumber kehidupan utama warganya masih berkaitan erat dengan usaha tani, termasuk meramu hasil hutan dan berternak yang diiringi dengan pemeliharaan ikan di tambak-tambak kecil tradisional. Jenis usaha tani cenderung bersifat untuk memenuhi kebutuhan sehari-hari. Teknologi pertanian yang dipakai masih rendah, tenaga hewan dan manusia merupakan sumber utama energi teknologi usaha taninya. Hubungan antar personal dan atau kelompok (masyarakat) sering didasarkan dan diikat atas adat istiadat yang ketat. Pengendalian atau pengawasan sosial (social control) dilaksanakan atas dasar kekeluargaan dan kebanyakan desa seperti ini berlokasi jauh dari pusat-pusat kegiatan ekonomi dan pusat kota dan sumberdaya manusia juga masih rendah serta masih sangat kurangnya prasarana dan sarana seperti infrastruktur jalan, pendidikan kesehatan.

b) desa swakarya (transisional), merupakan tipe desa yang tingkatannya dianggap lebih berkembang lagi dibandingkan desa swadaya. Adat yang merupakan tatanan hidup bermasyarakat sudah mulai mendapatkan perubahan-perubahan sesuai dengan perubahan yang terjadi dalam aspek kehidupan sosial budaya lainnya, adanya pengaruh dari luar sehingga mengakibatkan perubahan pola pikir dan sarana prasarana mulaimeningkat.

c) desa swasembada (modern), merupakan tipe desa yang maju dan lebih berkembang dibandingkan tipe-tipe desa terdahulu. Prasarana desa sudah baik, beraspal dan terpelihara pula dengan baik. Warganya telah memiliki pendidikan setingkat dengan sekolah menengah lanjuatan atas. Mata pencaharian sudah amat bervariasi dan tidak lagi berpegang teguh pada usaha tani yang diusahakan sendiri. Masyarakat tidak lagi berpegang teguh dengan adatnya tetapi ketaatan kepada syariat agama terus berkembang sejalan dengan perbaikan pendidikan dan sarana dan prasarana relatif lengkap dan modern

Berdasarkan aspek topografi dan kemampuan keswadayaan terlihat bahwa masing-masing desa mempunyai ciri dan karakteristik yang berbeda, perbedaan tersebut tidak terlepas dari kondisi dari desa itu sendiri. Oleh karenanya dalam melaksanakan program pembangunan di suatu desa belum tentu sama dengan pembangunan yang akan dilakukan di desa lain. Program yang akan dilaksanakan tentu harus dilihat dari bagaimana karakteristik dan kebutuhan dari masyarakat desa, dengan demikian maka program yang akan dilakukan dapat mencapai apa yang diharapkan oleh masyarakat itu sendiri.

\section{Pembangunan Desa}

Pembangunan desa merupakan seluruh kegiatan pembangunan di desa dan meliputi seluruh aspek kehidupan masyarakat yang dilaksanakan secara terpadu dengan mengembangkan swadaya gotong-royong, dengan tujuan untuk meningkatkan kesejahteraan masyarakat desa berdasarkan kemampuan dan potensi Sumber Daya Alam (SDA) mereka melalui peningkatan kualitas hidup, ketrampilan dan prakarsa masyarakat (Adisasmita, 2006:4). Lebih lanjut Chittoo dan Suntoo (2012) menyatakan bahwa pembangunan desa merupakan proses pertumbuhan dan kemajuan ekonomi pedesaan dan peningkatan kesejahteraan dan kesejahteraan masyarakat lokal. Kemudian menurut Howell dan Chisolm (2006) Pembangunan desa merupakan upaya yang dilakukan untuk memperbaiki dan meningkatkan kehidupan masyarakat desa, terutama pembangunan ekonomi, seperti ekspansi bisnis, pengembangan kewirausahaan dan pengembangan pariwisata.

Ada dua alasan mengapa permasalahan pembangunan desa masih relevan dibahas, pertama kendati dalam dua dasawarsa terakhir perkembangan kota semakin maju tetapi perkembangan perdesaan justru sebaliknya, sedangkan wilayah negara didominasi oleh daerah perdesaan; dan Kedua kendati sejak tahun 1970-an pemerintah Orde baru mencanangkan berbagai macam kebijaksanaan dan program pembangunan perdesaan, secara umum kondisi sosial ekonomi desa 
masih memperhatikan dan persoalan kemiskinan dan kesenjangan menjadi masalah krusial di perdesaan (Usman, 2012:29).

Menurut Fernando (2008) ada tiga dimensi dalam pembangunan perdesaan, yakni : 1) dimensi ekonomi, yakni mencakup penyediaan baik kapasitas maupun peluang bagi masyarakat miskin dan masyarakat berpenghasilan rendah perdesaan terutama sekali untuk mendapatkan manfaat dari proses pertumbuhan ekonomi, termasuk kebijakan untuk mengurangi ketidakmerataan intra maupun antar sektor; 2) dimensi sosial, yakni dimensi yang mendukung pembangunan sosial masyarakat berpendapatan rendah dan kelompok-kelompok masyarakat yang tidak beruntung, menghilangkan ketidakmerataan dalam beberapa indikator sosial serta penyediaan jaringan pengamanan sosial; dan

3) dimensi politik, yakni memperbaiki peluang masyarakat miskin dan masyarakat berpenghasilan rendah untuk dapat berpartisipasi secara efektif dan setara dalam proses politik pada tingkat perdesaan Arsyad et.al (2011:18-19). Pendapat senada dalam pembangunan berbasis lokal Arsyad, et.al (2011:19) mengungkapkan ada tiga dimensi dalam pembangunan desa, yakni 1) dimensi ekonomi, 2) dimensi kelembagaan, dan 3) dimensi politik. Sedangkan Harjanto (2011:126) menyatakan ada tiga dimensi dalam pembangunan desa, yaitu; 1) dimensi psikologis, yakni membangun hubungan erat antara petugas lapangan dengan sejumlah kecil petani untuk menumbuhkan kepercayaan pada petani, 2) dimensi teknologis, menggunakan demonstration plot untuk mentransfer pengetahuan dan meningkatkan produksi pangan, dan 3) dimensi kelembagaan, melaksanakan proses institution building, antara lain pembentukan koperasi (KUD) untuk melayani kredit dan membantu pemasaran. Dimensi-dimensi ini akan dibahas dalam bagian model-model pembangunan desa. Dimensi-dimensi tersebut akan dijadikan batu sandaran bagi pemerintah untuk melakukan pembangunan di daerah tertinggal.

Sehubungan dengan beberapa dimensi di atas, maka dalam pembangunan terkandung beberapa unsur, yakni: 1) Perubahan, yaitu perubahan dari sesuatu yang dianggap masih kurang menuju kesempurnaan; 2) Tujuan, yaitu tujuan yang diarahkan dari, oleh dan untuk rakyat (manusia) menuju pelastarian, kesejahteraan dan kebahagiaan hidup yang lebih baik lagi; dan 3) Potensi, yaitu potensi masyarakat yang terdapat dalam masyarakat itu sendiri yang kemudian dapat digunakan untuk mendukung perencanaan pembangunan (Suryono, 2010).

Untuk melakukan itu semua, negara (pemerintah) mempunyai peran yang sangat besar, karena tanpa ada keterlibatan dari pemerintah, terutama dalam hal anggaran maka pembangunan di perdesaan akan terlambat. Walaupun otonomi desa itu diberikan tetapi desa mempunyai anggaran yang sangat terbatas, disi lain bahwa tidak semua desa mempunyai sumber daya yang mempuni.

Seiring dengan adanya otonomi daerah, maka prinsip-prinsip pembangunan pedesaan adalah (1) transparansi (terbuka), (2) partisipatif, (3) dapat dinikmati masyarakat, (4) dapat dipertanggungjawabkan (akuntabilitas), dan (5) berkelanjutan (sustainable) (Adisasmita, 2006:19). Kegiatan-kegiatan pembangunan yang dilakukan dapat dilanjutkan dan dikembangkan ke seluruh pelosok daerah, untuk seluruh lapisan masyarakat. Pembangunan itu pada dasarnya adalah dari, oleh, dan untuk seluruh rakyat. Oleh karena itu pelibatan masyarakat seharusnya diajak untuk menentukan visi pembangunan masa depan yang akan diwujudkan. Masa depan merupakan impian tentang keadaan masa depan yang lebih baik dan lebih indah dalam arti tercapainya tingkat kemakmuran yang lebih tinggi.

Pembangunan pedesaan juga dilakukan dengan pendekatan secara multisektoral (holistik), partisipatif, berlandaskan pada semangat kemandirian, berwawasan lingkungan dan keberkelanjutan serta melaksanakan pemanfaatan sumberdaya pembangunan secara serasi selaras dan sinergis dan berkeadilan. Dalam artikelnya mengenai pembangunan desa tertinggal, Hardi (2010) mengajukan beberapa strategi dalam meingkatkan pembangunan di desa tertinggal, yakni:

1) Pembangunan daerah tertinggal disesuaikan dengan kebutuhan dan kondisi masing-masing daerah

2).Pengembangan ekonomi lokal, strategi ini diarahkan untuk mengembangkan ekonomi daerah tertinggal dengan didasarkan pada pendayagunaan potensi sumberdaya lokal (sumberdaya 
manusia, sumberdaya kelembagaan, serta sumberdaya fisik) yang dimiliki masing-masing daerah, oleh pemerintah dan masyarakat, melalui pemerintah daerah maupun kelompok- kelompok kelembagaan berbasis masyarakat yang ada.

3).Pemberdayaan Masyarakat, strategi ini diarahkan untuk meningkatkan kemampuan masyarakat untuk berperan aktif dalam kegiatan sosial, budaya, ekonomi, dan politik

4).Perluasan Kesempatan, strategi ini diarahkan untuk membuka keterisolasian daerah tertinggal agar mempunyai keterkaitan dengan daerah maju

5).Peningkatan Kapasitas, strategi ini diarahkan untuk meningkatkan kapasitas kelembagaan dan sumberdaya manusia pemerintah dan masyarakat di daerah tertinggal.

6).Peningkatan Mitigasi, Rehabilitasi dan Peningkatan, strategi ini diarahkan untuk mengurangi resiko dan memulihkan dampak kerusakan yang diakibatkan oleh konflik dan bencana alam serta berbagai aspek dalam wilayah perbatasan.

Strategi-strategi di atas merupakan suatu upaya yang dilakukan secara menyeluruh dan terintegrasi dengan mengarahkan sumber daya dan potensi yang ada. Strategis tersebut dijadikan sebagai hal yang mendasar dalam melaksanakan kebijakan pembangunan desa tertinggal, pembangunan desa tertinggal merupakan pembangunan yang dilakukan secara menyeluruh. Dalam melaksanakan strategi itu, Adisasmita (2006:20) mengingatkan bahwa ada tiga prinsip pokok yang harus diperhatikan, yakni: 1) kebijaksanaan dan langkah-langkah pembangunan di setiap desa mengacu kepada, pencapaian sasaran pembangunan berdasarkan Trilogi Pembangunan. Ketiga unsur Trilogi Pembangunan tersebut yaitu a) pemerataan pembangunan dan hasil-hasilnya, b) pertumbuhan ekonomi yang cukup tinggi, dan c) stabilitas yang sehat dan dinamis, diterapkan di setiap sektor dan antar sektor di setiap daerah, termasuk desa dan kota, di setiap wilayah dan antar wilayah secara saling terkait, serta dikembangkan secara selaras dan terpadu. 2) pembangunan desa dilaksanakan dengan prinsip-prinsip pembangunan yang berkelanjutan. Penerapan prinsip pembangunan berkelanjutan mensyaratkan setiap daerah lebih mengandalkan sumber-sumber alam yang terbaharui sebagai sumber pertumbuhan. Disamping itu setiap desa perlu memanfaatkan SDM secara luas, memanfaatkan modal fisik, prasarana mesin-mesin, dan peralatan seefisien mungkin.

3) meningkatkan efisiensi masyarakat melalui kebijakan deregulasi, debirokratisasi dan desentralisasi dengan sebaik-baiknya.

Pada hakekatnya tujuan umum dari pembangunan pedesaan adalah meningkatkan kualitas hidup masyarakat pedesaan melalui pencapaian kemajuan sosial dan ekonomi secara berkesinambungan dengan tetap memperhatikan persamaan hak dan menjunjung tinggi prinsipprinsip keadilan bagi masyarakat secara berkelanjutan. Secara singkat dapat dikemukakan bahwa tujuan pembangunan perdesaan adalah untuk peningkatan perbaikan kualitas hidup masyarakat secara multidimensional (improving quality of life) yakni meningkatkan pertumbuhan ekonomi, politik dan hak-hak sosial dari semua orang yang ada di desa-desa (Chittoo dan Suntoo, 2012)

Pembangunan pedesaan yang dilaksanakan harus sesuai dengan masalah yang dihadapi, potensi yang dimiliki, aspirasi masyarakat dan prioritas pembangunan pedesaan yang telah ditetapkan. Sasaran umum yang diharapkan dapat dicapai adalah pertumbuhan ekonomi pedesaan berbasis sumberdaya pertanian (agricultural resource based) yang ditunjang oleh kegiatan sektor non pertanian dengan memperhatikan kelestarian lingkungan dan kebutuhan masyarakat kecil. untuk itu Adisasmita (2006:24) menyatakan bahwa sasaran umum dalam pembangunan desa tertinggal dapat dikelompokkan menjadi beberapa sasaran sebagai berikut:

1) Tersedianya infrastruktur fisik dan sosial yang mencakup jaringan jalan, fasilitas pendidikan dan kesehatan yang tersebar di seluruh wilayah.

2) Terlaksananya pembangunan ekonomi yang mencakup ketersediaan sumber-sumber penghasilan, produktivitas pertanian yang tinggi, dan tingkat efisiensi yang tinggi dalam pemanfaatan sumberdaya alam. 
3) Terciptanya kelestarian lingkungan yang meliputi terciptanya kesadaran akan arti pentingaya lingkungan, berkembangnya kepedulian lingkungan semua pihak, dan adanya upaya nyata untuk kerusakan dan pencemaran lingkungan yang terjadi.

Sasaran pembangunan di atas tidak terlepas dari kompleksitas persoalan yang dihadapi oleh desa tertinggal. Dan mengacu pada sasaran tersebut, maka pembangunan pedesaan harus diletakkan dalam konteks: 1) sebagai upaya mempercepat pembangunan pedesaan melalui penyediaan prasarana dan sarana pembangunan untuk memberdayakan masyarakat, dan 2) sebagai upaya mempercepat dan memperkokoh pembangunan ekonomi daerah dalam arti luas secara efektif dan kokoh serta selalu berlandaskan pada pembangunan yang berkelanjutan (sustainable development) . Dengan demikian maka program pembangunan perdesaan, pada prinsipnya bertujuan untuk meningkatkan kesejahteraan masyarakat perdesaan, mempercepat kemajuan kegiatan ekonomi perdesaan yang berkeadilan, dan mempercepat industrialisasi perdesaan dengan selalu memperhatikan keberlanjutan lingkungan..

Dari beberapa hal yang diuraikan di atas dapat dikatakan bahwa secara umum terdapat dua aspek penting yang menjadi objek dalam pembangunan desa pembangunan, yakni : pertama pembangunan desa dalam aspek fisik, yaitu pembangunan yang objek utamanya dalam aspek fisik (sarana, prasarana dan manusia) di pedesaan seperti jalan desa, bangunan rumah, pemukiman, jembatan, bendungan, irigasi, sarana ibadah, pendidikan dan kesehatan Kedua: pembangunan dalam aspek pemberdayaan masyarakat, yaitu pembangunan yang objek utamanya aspek pengembangan dan peningkatan kemampuan, ketrampilan dan memberdayakan masyarakat melalui pendidikan dan pelatihan, pembinaan usaha ekonomi, kesehatan, spiritual, pengembangan kapasitas masyarakat individu maupun kelembagaan yang ada didesa dan sebagainya. Tujuan utamanya adalah untuk membantu masyarakat yang masih tergolong marjinal agar dapat melepaskan diri dari berbagai belenggu keterbelakangan sosial, ekonomi, politik dan sebagainya. keterlibatan masyarakat sangat diperlukan dalam pembangunan desa. karena proses pembangunan desa bukan hanya sebatas membangun prasarana dan sarana yang diperlukan, tetapi proses pembangunan desa merupakan bagian dari pemberdayaan dan peningkatan kapasitas masyarakat pedesaan.

\section{Model Pembangunan Desa}

Untuk memudahkan dalam melaksanakan suatu program dibutuhkan suatu bentuk konseptual yang dijadikan sebagai acuan ataupun panduan dalam melaksanakan program tersebut. Dari konsepkonsep yang telah ditentukan kemudian akan dibuat suatu model. Secara sederhana Bullock dan Stallybrass (1997) dalam Wahab (2011:64) menyatakan bahwa model adalah - a representation of something else, designed for a specific purpose" (suatu pengejawantahan dari sesuatu yang lain, yang dirancang untuk tujuan tertentu). Pendapat yang hampir sama dinyatakan oleh Dye (197:39) bahwa - a model is merely an abstraction or representation of political lifell (model merupakan suatu upaya penyederhanaan dan pengejawantahan dari keyataan politik). Dengan demikian bahwa model dapat dikatakan sebagai suatu konsep atau pola yang dibuat secara sederhana sebagai upaya untuk menggambarkan suatu keadaan (publik) melalui kebijakan publik untuk memecahkan masalah dan mencapai tujuan publik. Model dalam pembangunan desa merupakan suatu bentuk atau pola yang dibuat untuk mencapai tujuan dari program pembangunan desa secara efektif.

Disadari bahwa masing-masing desa mempunyai karakteristik dan potensi yang berbeda, maka diperlukan suatu pola atau model yang dianggap sesuai dengan kondisi, kebutuhan dan potensi desa tersebut agar program-program pembangunan yang dilakukan dapat memberikan dampak positif dalam meningkatkan kualitas hidup mereka sehingga mereka bisa keluar dari ketertinggalan dan kemiskinan. oleh karena itu dalam bagian ini akan disajikan beberapa model pembangunan desa, yakni : 
Model ini dikembangkan oleh Inanyatullah (1977) dalam Winarno (2008:19) menyatakan bahwa ada tiga model dalam pembangunan desa, yakni model intervensi rendah (model produktivitas), model intervensi menengah (model solidaritas) dan model intevensi tinggi (model pemerataan atau equality).

Pertama Model Intervensi Rendah (Model Produktivitas). Model ini mendiaknosa bahwa yang menyebabkan ketertinggalan desa (rural underdevelopment) adalah langkanya teknologi yang digunakan untuk meningkatkan produktivitas, ketidaktahuan, kebodohan, ketakhayulan, buta aksara dan angka . Oleh karena itu upaya pembangunan ditujukan untuk meningkatkan produktivitas (pertanian) tanpa melakukan perubahan-perubahan penting dan substansial terhadap struktur sosial yang sudah ada.

Model ini diarahkan untuk membantu penduduk lokal yang mempunyai modal, sumbersumber daya, ketrampilan dan motivasi yang tinggi untuk meningkatkan produktivitas mereka. Oleh karena itu pemerintah harus memberikan perhatian kepada penduduk desa yang masuk kategori ini dengan memberikan kemudahan-kemudahan untuk memperoleh input bagi produktivitas yang tinggi dan pembaharuan-pembaharuan teknis. Pemerintah juga perlu memberikan insentif yang lebih besar kepada penduduk desa yang mengorganisir bagi pertukaran dan keuntungan dan bukan untuk konsumsi sendiri.

Kedua adalah Model Intervensi Menengah (model solidaritas). Menurut Inanyatullah bahwa yang menyebabkan ketertinggalan desa (rural underdevelopment) adalah kemerosotan dan degradasi masyarakat desa serta langkanya lembaga-lembaga desa yang dapat meningkatkan peran aktif penduduk desa tersebut. Untuk memecahkan masalah tersebut adalah dengan membentuk lembagalembaga baru, memodernisasi elit desa dan mendifusikan ketrampilan-ketrampilan berorganisasi dan menjalin hubungan menjalin hubungan antara anggota masyarakat untuk lebih harmonsi dalam organisasi yang mereka bentuk.

Intervensi yang dilakukan hanya terbatas pada lembaga-lembaga desa dengan perubahan yang bersifat moderat dalam sistem kepemilikan tanah dan dalam struktur kekuasaan desa. Dengan demikan dapat dikatakan bahwa model ini bersifat toleran terhadap tingkat ketidakmerataan (inequality) yang moderat dan bersifat ambivalen dalam hal seberapa jauh sistem sosial pedesaan tradisional perlu dimodernisir, dan seberapa jauh struktur tradisional perlu diperlemah guna melambangkan struktur kelembagaan baru yang mampu meningkatkan peran serta aktif penduduk desa.

Negara (Pemerintah) hanya melakukan pengembangan kerajinan dan ketrampilan masyarakat di pedesaan, mendorong kegiatan kegiatan kelembagaan seperti koperasi melalui pembentukan dan penyediaan kredit yang berasal dari masyarakat desa, yang ditujukan untuk mengurangi kegiatan ekonomi yang bersifat eksploitatif di daerah pedesaan untuk memperkuat produsen dan konsumen di desa.

Walaupun ada kekhawatiran karena lembaga tersebut baru dan dibentuk bukan inisiatif dari masyarakat desa, bahkan kurang dipahami oleh masyarakat atau bernuansa proyek pemerintah, maka modal-modal stimulan yang diberikan pemerintah melalui lembaga (koperasi) bisa macet atau gagal. Oleh karena itu harus adanya sosialisasi dan melakukan pelatihan-pelatihan kepada masyarakat desa mengenai tujuan dan kegiatan yang dilakukan oleh koperasi agar masyarakar desa dapat memahami tujuan dan manfaat dari koperasi tersebut. Sehingga dengan terbentuknya lembaga baru tersebut perekonomian dan pendapatan masyarakat setempat bisa meningkat.

Ketiga Model Intevensi Tinggi (model pemerataan atau equality). Model ini mengasumsikan bahwa yang menyebabkan desa itu tertinggal adalah karena tidak meratanya pendapatan, kekayaan dan kekuasaan di kalangangan penduduk desa. Oleh karena itu menurut Inanyatullah untuk meningkatkan pembangunan di desa yang tertinggal karena kondisi di atas adalah melakukan nasionalisasi, yakni melalui 1) penguasaan oleh aparat pemerintah pada tingkat nasional melalui organisasi politik yang relevan dengan masyarakat bawah guna memudahkan 
dalam melakukan transformasi masyarakat, dan 2) perjuangan yang terorganisir untuk menentang kelompok petani-petani kaya di tingkat lokal dengan cara mengambil alih sebagian struktur kekuasaan lokal dan mendistribusikan sebagian tanah dan sasaran produksi lainnya kepada petani yang berpenghasilan rendah atau yang tidak mempunyai lahan pertanian.

Adapun tujuan dari model ini adalah mempersempit, atau jika memungkinkan menghapus ketidakmerataan sosial, ekonomi serta kegiatan-kegiatan ekonomi dari penduduk desa yang kaya yang dapat merugikan lapisan penduduk berpenghasilan rendah. Dengan perubahan kepemilikan melalui program pembagian lahan kepada kelompok tani yang tidak mempunyai lahan diharapkan akan mampu meningkatkan pendapatan dan pemerataan bagi semua petani di desa tersebut.

Ketiga model intervensi di atas secara umum berawal dari asumsi bahwa yang menyebabkan desa itu tertinggal adalah karena produktivitas pertanian yang tidak maksimal, adanya ketidakmerataan terhadap kepemilikan dan pengasaan lahan pertanian dan tidak adanya dukungan kelembagaan desa yang mampu menjadi motor penggerak perekonomian warga desa tersebut. Untuk itu melalui intervensi ini, produktivitas hasil pertanian dan kerekonomian masyarakat dapat meningkat secara berkeninambungan dan berkeadilan. Dalam kaitan ini Barca, Fabrizio, et.al (2012) mengungkapkan bahwa intervensi yang dilakukan oleh pemerintah dalam meningkatkan pembangunan di suatu daerah mutlak dilakukan agar pembangunan di daerah tersebut cepat berkembang. Mereka berasumsi tanpa ada intervensi dari pemerintah maka perkembangan daerah tersebut menjadi lambat. Dengan melakukan intervensi dengan melihat pada permasalahan yang dialami oleh desa tersebut maka permasalahan yang dialami oleh masyarakat dapat teratasi dengan baik. Intervensi yang dilakukan tentu dengan tujuan untuk meningkatkan pertumbuhan ekonomi dari masyarakat desa.

Model pembambangunan ini menurut Arsyad, et.al (2011) lebih menekankan pada model dari atas top down karena walaupun program atau kegiatan yang diluncurkan itu berdasarkan kondisi masyarakan desa tetapi dalam penentuan program tidak melibatkan masyarakat dan ditentukan oleh pemerintah sendiri.

\section{b). Model Pembangunan Berbasis Lokal}

Konsep pembangunan yang bersifat bottom up yang telah diterapkan mulai dari Musrenbang tingkat desa hingga kini belum dilaksanakan dengan optimal, seperti adanya usulan dari desa yang dirumuskan oleh masyarakat desa seringkali diintervensi oleh pemerintah (Winarno, 2006) bahkan dalam pelaksanaan dan pengawasan program-program pembangunan, masyarakat desa tidak dilibatkan secara maksimal (Arsyad, et.al, 2011) sehingga banyak program-program pembangunan pedesaan tidak berhasil karena tidak sesuai dengan kebutuhan masyarakat banyak. Untuk itu melalui model pembangunan berbasis lokal, masyarakat desa bisa terlibat dalam setiap proses pembangunan, mulai dari pengambilan keputusan, implementasi keputusan, pemanfaatan (Benefits) hasil program pembangunan hingga pada evaluasi program pembangunan (Cohen dan Uphoff, 1977, Adisasmita, 2006 dan Arsyad, et.al 2011).

Model pembangunan berbasis lokal menitik beratkan pada pertumbuhan ekonomi dan perubahan struktural yang dimotori oleh masyarakat lokal dengan memanfaatkan potensi-potensi yang ada dalam upaya untuk memperbaiki tingkat kesejahteraan masyarakat. Manurut Corten, yang dikutip oleh Suryono (2010:12) pembangunan yang berorientasi pada masyarakat (people centered development) menginginkan alternatif paradigma pembangunan yang tidak hanya berorientasi pada produksi dan kebutuhan semata, akan tetapi juga berorientasi pada manusia.

Pembangunan yang berdimensi kerakyatan memberi peran kepada individu bukan sebagai subyek, tetapi sebagai aktor yang menetapkan tujuan, mengendalikan sumber daya dan mengarahkan proses yang mempengaruhi kebutuhannya (Suryono, 2010:12). Di sini pemerintah hanya bertindak sebagai fasilitator dan koordinator (Chittoo dan Suntoo, 2012). Pemerintah memberikan fasilitas dan melakukan koordinasi terhadap apa yang menjadi kebutuhan masyarakat yang kemudian dituangkan dalam suatu kebijakan pembangunan di desa tersebut. Strategi yang 
digunanakan adalah dengan pendekatan yang mengandalkan pada kebutuhan, seluruh potensi dan perilaku lokal dari suatu daerah tertentu (locality). Oleh karena itu karakteristik utama dari model ini adalah

1) Kerangka pembangunan di dalam kerangka kewilayahan bukan sektoral. Wilayah tidak hanya diangkap sebagai wilayah dimana sumberdaya dan kegiatan ekonomi dan terjadi tetapi juga sebagai agen perubahan karena perusahaan dan pelaku-pelaku lainnya di dalam wilayah tersebut berinteraksi satu sama lainnya bersama-sama membangun perekonomian dan masyarakat;

2) Kegiatan ekonomi dan kegiatan lainnya diarahkan untuk dimaksimalkan manfaat bagi masyarakat lokal melalui pemanfaat sumberdaya lokal, fisikal maupun budayanya

3) Pembangunan dikontekstualkan melalui pemusatan perhatian pada kebutuhan, kapasitas dan perspektif masyarakat lokal, yang berarti bahwa suatu wilayah mengembangkan kapasitasnya untuk membangun sosial ekonomi yang khas wilayah tersebut;

4) Pembangunan tidak terbatas hanya pada pembangunan ekonomi saja, tetapi juga untuk memperlakukan masalah-masalah ekonomi, ekologis dan sosial secara setara sehingga dapat diharapkan untuk menciptakan pembangunan berkelanjutan (sustanaible development);

5) Partisipasi masyarakat lokal dalam proses pengambilan keputusan politik sangat penting karena strategi ini terutama sekali ditentukan sendiri oleh masyarakat lokal dengan mengacu pada kebutuhan lokal.

Menurut Amadi (2012) bahwa strategi pembangunan pedesaan seperti ini dapat mewujudkan melalui motivasi, keterlibatan aktif dan organisasi di tingkat akar rumput masyarakat pedesaan dalam konseptualisasi dan merancang kebijakan dan program dimaksudkan untuk mereka. Strategi ini bukan hanya memperbaiki dari sisi produktif (pertanian, industri dan jasa) tetapi juga mendorong dan meningkatkan dimensi sosial dan budaya yang mempengaruhi kebihupan masyarakat.

Dalam model pembangunan berbasis lokal, terdapat 3 (tiga) dimensi yang menjadi sasaran, yakni 1) dimensi ekonomi yang ditandai oleh sistem produksi khusus yang memungkinkan para entrepreneur menggunakan secara efisian faktor-faktor produksi dan mencapai produktivitas yang memungkinkan mereka bisa kompetitif di pasar; 2) dimensi kelembagaan, dimana para pelaku ekonomi dan sosial terintegrasi di dalam institusi lokal untuk membentuk sistem hubungan yang kompleks yang memadukan nilai-nilai sosial dan budaya dalam pembangunan; dan 3) dimensi politik, yang tercermin pada inisiatif lokal yang menekankan pada penciptaan lingkungan lokal yang menstimulus produksi dan membuat pembangunan yang berkelanjutan (Arsyad, et.al, 2011).

Melalui model pembangunan ini maka perumusan dan pelaksanaan program-program pembangunan untuk meningkatkan pembangunan pedesaan dapat terlaksana secara reliable, acceptable, implementable dan Workable (Adisasmita, 2006:132). Reliable maksudnya bahwa program pembangunan yang dirumuskan itu menyakinkan dan dipercaya karena dilakukan oleh seluruh atau kelompok yang mewakili anggota masyarakat yang merupakan stakeholder atau kelompok yang berkepentingan. Acceptable artinya pembangunan tersebut dapat diterima oleh masyarakat luas, karena program yang akan diimplementasikan tersebut disusun dan dirumuskan bersama oleh masyarakat. Implementable yakni program tersebut dapat dilaksanakan karena disusun berdasarkan potensi, kondisi dan kemampuan yang dimiliki serta kebutuhan masyarakat desa setempat. Workable artinya program yang telah dirumuskan dapat dilaksanakan oleh pemerintah dan terutama masyarakat setempat, dan apabila ada hambatan atau kekurangan dalam implementasinya maka akan bisa diatasi oleh oleh masyarakat setempat, baik dalam hal dana, material, tenaga maupun pemikiran sesuai dengan kemampuan yang mereka miliki.

Dalam model ini, komunikasi mempunyai peran yang sangat penting, karena kegagalan dari program ataupun proyek pembangunan pedesaan antara lain disebabkan karena program maupun proyek tersebut tidak dikomunikasikan dengan baik kepada masyarakat (Acharya, 2010). Karena melalui komunikasi dapat menciptakan partisipasi dan rasa memiliki di kalangan masyarakat 
pedesaan (Hagul, 1992) dan keberhasilan pembangunan tergantung dari tingkat partisipasi masyarakat dalam kehidupan sosial-ekonomi (Chmielinski, 2011).

Melalui model pembangunan berbasis lokal yang partisipatif, masyarakat desa dapat terlibat dalam semua proses dan tahap dari pelaksanaan program pembangunan yang dilakukan. Pembangunan dilakukan secara terus-menerus dengan menempatkan manusia sebagai posisi yang wajar yakni sebagai obyek dan subyek pembangunan unutuk mampu mengembangkan dan memberdayakan diri sendiri (Suryono, 2011:38).

Apabila dicermati bahwa model pembangunan perdesaan yang berbasis lokal ini lebih bersifat dari bawah bottom up karena masyarakat dilibatkan dalam setiap proses pembangunan dan konsepnya adalah bahwa masyarakat adalah sebagai pelaku utama dalam program tersebut, sedangkan pemerintah adalah memfasilitasi apa yang menjadi kebutuhan dan tuntutan masyarakat yang disesuaikan dengan kondisi yang ada.

\section{c). Model Pembangunan Desa Terpadu}

Model ini merupakan model penggabungan antara model pembangunan yang bersifat top down seperti dalam model intervensi dan model pembangunan desa yang bersifat bottom up dalam model pembangunan desa berbasis lokal. Menurut Parsons (2008) bahwa model pembangunan bawah ke atas (bottom-up) menyempingkan pertimbangan seberapa riilkah orang berperilaku secara kontekstual dan lebih memahami hubungan logis antara input, proses dan uotput dan menjadikan orang melakukan apa yang diperintahkan serta mengontrol setiap tahapan dalam sebuah sistem, sehingga apabila implementasi itu gagal yakni tujuan kebijakan tidak tercapai, disebabkan karena pemilihan strategi dan instrumen yang digunakan keliru. Sedangkan pendekatan bottom-up adalah kebalikan dari pendekatan top-down, yakni lebih menyoroti pelaksanaan kebijakan yang terformulasi berdasarkan inisiatif dari masyarakat setempat. Asumsi ini dapat dimengerti melalui argumentasi bahwa masalah dan persoalan yang terjadi dilevel daerah/desa hanya dapat dimengerti oleh masyarakat setempat. Menurut Parson (2008) bahwa pendekatan bottom-up lebih memberikan keleluasaan kepada pelaksana di lapangan dalam penerapan kebijakan.

Pendekatan bottom-up mulai dikembangkan setelah melihat kekurang-berhasilan dari pendekatan top-down. Namun demikian bukan berarti pendekatan top-down ditinggalkan. Tanpa ada arahan dari atas (pemerintah) barangkali pembangunan yang akan dilakukan menjadi bias, karena pada umumnya pendekatan pembangunan dari bawah saja kurang bisa menjamin perwujudan peningkatan produktivitas masyarakat (Sitompul, 2009:23). Oleh karena itu pendekatan gabungan yang memadukan antara pendekatan bottom-up dan pendekatan top-down merupakan suatu pendekatan yang anggap sangat realistis dan produktif (Parsons, 2008).

Sejalan dengan pandangan Parson dan Sitompul di atas, Waterson dalam Fakih (2006) mengungkapkan bahwa pendekatan top-down terhadap pembangunan tidak berhasil dalam memenuhi kebutuhan sosial masyarakat miskin diperdesaan dan strategi yang hanya memfokuskan pada pada pertanian akan membuat jurang semakin lebar antara yang kaya dan miskin. Untuk itu ia mengungkapkan bahwa dengan memadukan pendekatan top-down dan bottom-up akan terakomodasi semua. Pemerintah mempunyai kebijakan terhadap pembangunan akan disinergikan dengan apa yang menjadi kabutuhan masyarakat di perdesaan.

\section{Indikator Keberhasilan Pembangunan Desa}

Tingkat keberhasilan pembangunan perdesaan dapat dikur dengan menggunakan beberapa indikator baik yang bersifat kuantitatif maupun kualitatif. Meskipun indikator-indokator tersebut tidak dapat mencerminkan kondisi yang sebenarnya, namun indikator-indikator tersebut dapat digunakan sebagai proxies dari kemajuan pembangunan desa (Arsyad et.al, 2011:87). lebih lanjut dikatakan bahwa ada delapan indikator yang digunakan untuk mengetahui keberhasilan pembangunan perdesaan. 
1) Infrastruktur; terdiri dari infrastruktur fisik (transportasi, komunikasi, irigasi dan listrik), infrastruktur ekonomi (pasar, pertokoan koperasi, dan lain-lain), infrastruktur kesehatan (jumlah paramedis, fasilitas kesehatan, jarak ke hasilitas kesehatan, sanitasi), dan infrastruktur pendidikan (ketersediaan fasilitas pendidikan, rasio guru dan murid jarak menuju gedung sekolah lain-lain).

2) Pembangunan pertanian; dilihat dari porsi lahan sawah, lahan pertanian

3) Tingkat industrialisasi; diantaranya keberadaan usaha kecil dan menengah, sentra industri

4) Kondisi usaha non-pertanian; meliputi sektor pariwisata, jasa perbengkelan, rumah makan

5) Pendidikan dan kesehatan; meliputi tingkat melek huruf, pendidikan rata-rata, mordibitas dan tingkat kematian anak

6) Tingkat rawan bencana; meliputi banjir, longsor, kekeringan dan gempa

7) Aspek kelembagaan dan modal sosial; meliputi organisasi sosial masyarakat, ketersediaan perangkat desa, kegotong-royongan

8) Aspek sosial budaya; meliputi keragaman etnis, fasilitas rekreasi (alam,budaya)

Sedangkan dalam konteks pembangunan partisipatif, Adisasmita (2006:135-139) menyatakan bahwa indikator keberhasilan pembangunan dapat dilihat dari 1) tingkat kemampuan dan kemantapan pemerintahan desa; 2) kemampuan kepemimpinan desa dan respon anggota masyarakat yang dipimpin, yakni pemimpin yang persuasif, akomodatif, dinamis dan antisipatif; 3) keikutsertaan masyarakat dalam setiap tahap proses pembangunan; 4) bentuk kontribusi anggota masyarakat pembangunan; dan 5) partisipasi dalam hubungannya dengan desa lain yang terkait dengan pembangunan bersama. Indikator-indikator di atas sangat mumpuni untuk melihat keberhasilan dalam pembangunan perdesaan, terutam desa yang masih tertinggal, karena dengan kompleksitas permasalahan yang oleh desa tertinggal memudahkan dalam melakukan pengukuran dan melihat keberhasilan program pembangunan di desa tersebut.

\section{VII.Karakteristik Daerah Tertinggal}

Pembahasan pengenai daerah tertinggal biasanya mencakup masalah kemiskinan dan kesenjangan. Kendati dalam keseharian istilah kemiskinan acapkali dipakai silih berganti dengan kesenjangan/ketertinggalan. Pamahaman ini sepertinya perlu dilusurkan, karena pada hakekatnya kemiskinan dan kesenjangan/ketertinggalan itu sungguh berbeda. Kemiskinan merupakan suatu kondisi kehilangan (deprevation) terhadap sumber-sumber pemenuhan kebutuhan dasar yang berupa pangan, sandang, papan dan kesehatan. Mereka yang berada dalam katagori miskin biasanya hidup serba kekurangan. Sedangkan kesenjangan adalah sebuah kondisi dimana didalamnya terjadi ketimpangan akses dalam pembangunan, baik pendidikan, sosial maupun ekonomi.

Kesenjangan antar wilayah juga ditunjukkan oleh masih tingginya disparitas kualitas sumber daya manusia antarwilayah, perbedaan kemampuan perekonomian antardaerah, serta belum meratanya ketersediaan infrastruktur antarwilayah. Daerah-daerah dengan pencapaian pembangunan yang rendah dikategorikan sebagai daerah tertinggal, dan diperhitungkan memiliki indeks kemajuan pembangunan ekonomi dan sumberdaya manusia di bawah rata-rata indeks nasional. Persoalan daerah tertinggal dalam penanganannya bersifat lintas bidang, maka untuk mewujudkan pembangunan yang adil dan merata diperlukan percepatan pembangunan dengan didukung peran aktif dan kerjasama secara terpadu dari seluruh sector terkait.

Dalam Peraturan Menteri Negara PDT Nomor: 07/PER/M- PDT/III/2007 tentang Perubahan Keputusan Menteri Negara PDT Nomor 001/KEP/M-PDT/II/2005 tentang Strategi Nasional Pembangunan Daerah Tertinggal bahwa daerah tertinggal adalah daerah Kabupaten yang relatif kurang berkembang dibandingkan daerah lain dalam skala nasional, dan berpenduduk yang relatif tertinggal. Definisi tersebut berdasarkan pada kondisi sosial, ekonomi, budaya, dan wilayah (fungsi inter dan intra spasial baik pada aspek alam, aspek manusianya, maupun prasarana pendukungnya). Untuk menentukan daerah tersebut tertinggal ada beberapa kreteria secara umum yang digunakan, 
yakni : tingkat perekonomian masyarakat, sumberdaya manusia, prasarana (infrastruktur), kemampuan keuangan lokal (celah fiskal), aksesibilitas, dan karakteristik daerah. Kreterian lain yang juga hampir sama dinyatakan oleh Oppusunggu (2011) adalah sebagai berikut: 1) perekonomian suatu daerah memiliki PDB dan pendapatan per kapita yang rendah, dan tingkat kemiskinan yang tinggi; 2) sumber daya manusia daerah memiliki Indeks Pembangunan Manusia yang rendah; 3) sarana dan prasarana yang minim di bidang transportasi, energi, kesehatan, pendidikan, telekomunikasi dan perekonomian; dan 4) kemampuan keuangan daerah mempunyai Pendapatan Asli Daerah (PAD) dan Penerimaan dari Pemerintah rendah.

Dari uraian di atas, beberapa hal yang menyebabkan daerah itu tertinggal, yakni: 1) kondisi geografis. Umumnya secara geografis daerah tertinggal relatif sulit dijangkau karena letaknya yang jauh di pedalaman, perbukitan/pegunungan, kepulauan, pesisir, dan pulau-pulau terpencil sehingga sulit dijangkau jaringan baik transportasi maupun media komunikasi. 2) sumberdaya alam. Beberapa daerah tertinggal tidak memiliki potensi sumberdaya alam, daerah yang memiliki sumberdaya alam yang besar namun lingkungan sekitarnya merupakan daerah yang dilindungi atau tidak dapat dieksploitasi, dan daerah tertinggal akibat pemanfaatan sumberdaya alam yang berlebihan. 3) sumberdaya manusia. Pada umumnya masyarakat di daerah tertinggal mempunyai tingkat pendidikan, pengetahuan, dan keterampilan yang relatif rendah serta kelembagaan adat yang belum berkembang. 4) prasarana dan sarana. Keterbatasan prasarana dan sarana komunikasi, transportasi, air bersih, irigasi, kesehatan, pendidikan, dan pelayanan lainnya yang menyebabkan masyarakat di daerah tertinggal tersebut mengalami kesulitan untuk melakukan aktivitas ekonomi dan sosial. 5) Daerah Rawan Bencana dan Konflik Sosial. Seringnya suatu daerah mengalami bencana alam dan konflik sosial dapat menyebabkan terganggunya kegiatan pembangunan sosial dan ekonomi. 6) kebijakan pembangunan. Suatu daerah menjadi tertinggal dapat disebabkan oleh beberapa kebijakan yang tidak tepat seperti kurang memihak pada pembangunan daerah tertinggal, kesalahan pendekatan dan prioritas pembangunan, serta tidak dilibatkannya kelembagaan masyarakat adat dalam perencanaan dan pembangunan.

Sedangkan Hendrawan (2011) menyebutkan bahwa empat aspek yang membuat daerah tersebut menjadi tertinggal, yakni : pertama : aspek politik; Yang mana dalam menentukan arah kebijakan politik untuk daerah tertinggal, masih banyak terjadi ketimpangan. Pembanguan masih banyak dilakukan di pusat-pusat kota. Daerah tertinggal menjadi tertinggal karena pembangunan di daerah tersebut tidak terlaksana. Infrastruktur dan pelayanan umum masyarakat tidak dibangun. Otonomi daerah kurang berjalan untuk daerah-daerah tertentu diakibatkan daerah kurang memperoleh dana untuk melakukan pembangunan. Permasalahan ini perlu menjadi perhatian dari pemerintah pusat. Hal ini mengakibatkan daerah tertinggal seringkali terisolir dari dunia luar karena kurangnya pembangunan infrastruktur sehingga kawasan tersebut menjadi kawasan yang belum terjamah sehingga pembangunan kesejahteraan tidak merata

Kedua :Ekonomi. Kegiatan ekonomi tidak dipandang dari banyaknya penanaman modal asing yang masuk tetapi lebih dilihat dari berapa banyak pendapatan penduduk yang mengusahakan sumber daya alam di daerah tersebut. Kekayaan alam yang dimiliki tersebut digunakan sebesar- besarnya untuk kemakmuran rakyat dan digunakan pula untuk membiayai kinerja pemerintah pada daerah tertinggal yang bersangkutan. Ukuran dari daerah tertinggal yang memiliki kekurangan dalam bidang ekonomi adalah pendapatan per kapita. Pendapatan per kapita setiap daerah bisa berbeda-beda. Pendapatan tersebut diperhitungkan berdasarkan kemampuan seseorang untuk mencukupi kebutuhan primer dan dikatakan daerah tertinggal apabila mayoritas penduduk sulit untuk memenuhi kebutuhan primer. Hal ini dilihat juga dari angka pengangguran. Semakin banyak orang yang menganggur di dalam suatu daerah hal tersebut akan menyebabkan kemiskinan dan akhirnya tidak dapat memenuhi kebutuhan primer yang akhirnya menyebabkan daerah tersebut masuk ke dalam kategori daerah tertinggal.

Ketiga; Sosial dan Budaya. Sulitnya akses untuk pendidikan dari dunia luar membuat daerah tersebut menjadi sulit berkembang. Kurangnya prasarana menyebabkan pembangunan sumber daya 
manusia terhambat pula. Aspek pendidikan adalah salah satu kriteria dimana kehidupan sosial dan budaya berkembang pula. Keempat; Pertahanan dan keamanan. Pertahanan dan keamanan disini meliputi kepastian hukum yang ada. Kurangnya pengertian dan ketaatan warga masyarakat akan hukum dapat menyebabkan terganggunya pertahanan dan kemanan. Di mana peran dari aparat kepolisian atau aparat yang berwenang dalam pemerintahan merupakan salah satu hal yang membuat kawasan ini menjadi terbelakang. Tingginya tingkat peperangan antar warga dengan menggunakan senjata tradisional dan tidak menghiraukan aparat yang berwenang menjadi salah satu hal pelengkap. Jadi jika dilihat aspek pertahanan dan keamanan hanya pelengkap karena merupakan akibat bukan sebab dari tidak terpenuhinya keempat kategori di atas.

Melihat dari kandisi di atas terlihat bahwa ketertinggalan suatu wilayah merupakan produk dari situasi yang komplek. Menurut Usman (2012:23) bahwa situasi yang kompleks ini merupakan akumulasi dari interelasi dari berbagai macam faktor, seperti latar belakang historis, masalah produktivitas dan ketenagakerjaan, ketergantungan pada sektor pertanian, keterbatasan akses pada input produksi serta kondisi struktural sosial masyarakat itu sendiri. Dengan demikian, penjelasan mengenai daerah tertinggal, tidak hanya melibatkan analisis dalam dimensi kebijakan tetapi juga dimensi kultural dan struktural.

Dari uraian di atas dapat dikatakan bahwa daerah tertinggal didefinisikan sebagai suatu daerah, yang relatif kurang berkembang dibandingkan dengan daerah lainnya berdasarkan kondisi dan fungsi inter dan intra spasial, baik pada aspek alam yang meliputi sumberdaya alam, sumberdaya fisik, alam, ekologi, dan ekosistemnya; maupun aspek manusianya yang meliputi dimensi ekonomi, politik, sosial, budaya, dan prasarana pendukungnya.

\section{Kesimpulan}

Diskusi mengenai pembangunan perdesaan merupakan suatu dialog yang tidak habisnya karena masing-masing desa mempunyai karakteristik yang berbeda. Pembangunan desa merupakan upaya terencana yang dilakukan pemerintah bersama masyarakat untuk meningkat pembangunan di perdesaan. Dengan melihat berbagai karakteristik dan tipologi desa yang ada akan memberikan gambaran dalam melakukan kebijakan dalam pembangunan desa tersebut. Berbagai model yang ditawarkan di atas dapat dijadikan sebagai batu sandaran bagi

pemerintah untuk melakukan percepatan pembangunan di perdesaan, terutama di desa yang masih tertinggal. Masing-masing model tersebut mempunyai kelebihan dan kekurangannya. Oleh karena itu melalui tulisan sederhana ini dapat menambah khasanah teoritik bagi kita bahwa dalam pembangunan perdesaan itu memerlukan suatu model agar program-program yang akan dilaksanakan dapat memecahkan persoalan yang dialami oleh desa tertinggal.

$* * * * * *$

\section{DAFTAR PUSTAKA}

Acharya, Bala Ram. 2010. Dimenstion Of Rural Development in Nepal. DhulabinJournal of Sociology and Anthropology Vol.2.

Diakses melalui: www.nepjol.info/index.php/DSAJ/article/download

Adisasmita, Rahardjo. 2006. Membangun Desa Partisipatif. Graha Ilmu Yogyakarta.

Amadi, Ugochukwu P.N. 2012. Information and Communication Technologies (ICT) in the Implementation of Participatory Agricultural Reforms and Rural Development Initiatives in 
the South-Eastern Nigeria. Journal of Educational and Social Research. ISSN 2239-978X Vol. 2 (10) November 2012.

Arsyad, Linkolin, et,al. 2011. Strategi Pembangunan Perdesaan Barbasis Lokal. UPP STIM YKPN, Yogyakarta.

Barca, Fabrizio. Et al. 2012. The Case For Regional Development Intervention:Place-Based Versus Place-Neutral Approaches. Journal of Regional Science, vol. 52, no. 1, 2012, pp. 134-152. Diakses melalui: www.usergioarboleda.edu.co/.../THE-CASE-FOR-REGIONAL-

Chmielinski, Powel. 2011. On Community Involevement IN Rural Development - A Case Of Leader Programme In Poland Interdisciplinary Approach To Economics And Sociology. Economics \& Sociology, ISSN 2071-789X. Vol. 4, No 2, 2011, pp.

Chittoo dan Suntoo,Rajen. 2012. Rural Development in a Fast Developing African Society: The Case of Mauritius. Global Journal of HUMAN SOCIAL SCIENCE. Volume 12Issue 4 Version 1.0 February 2012. Type: Double Blind Peer Reviewed International Research Journal Publisher: Global Journals Inc. (USA).

Cohen, John dan Uphoff, Norman T. 1977. Rural Development Participation: Konsep and Measures for Project Desaign-Implementation and Evaluation. New York: Cornell University Press.

Dye, Thomas R. 1995. Understanding Public Policy. New Jersey: Practice Hill

Fakih, Mansour. 2006. Runtuhnya Teori Pembangunan dan Globalisasi. Insist Press.

Friedman, Jhon. 1992. Empowerment: The Politics Of Alternatif Development. Massachusetts: Blackwell Publishers

Hagul, Feter. 1992. Pembangunan Desa dan Lembaga Swadaya Masyarakat. Rajawali, Jakarta.

Hardi, Ode Sofyan, 2010. Implementasi Model Pembangunan Perdesaan Dalam Peningkatan Pembangunan Desa Tertinggal. jurnal Region Volume II. No. 2 September 2010

Diakses melalui: http://www.ejournal-nisma.net/ojs/index.php/region/article/

Hardjanto, Imam. 2011. Teori Pembangunan. UB Press.

Hendrawan, Daniel. 2011. Analisi Yuridis Percepatan Pembangunan Daerah Tertinggal Sebagai Bagian Dari Perwujudan Negara Kesejahteraan. Jurnal Institut Liemena, Pembangunan daerah Tertinggal. Vol.3 No.2 Okt 2011. Diakses melalui: http://www.leimena.org/id/page/v/548/.......

Howell, Robin dan Chisolm (2006) Rural Leadership: A Case Study Of The Factors That Influence Economic Development In Two Rural Communities In South Carolina. UMI Microform. United States.

Joshi, Sudiksha \& Gebremedhin, Tesfa. 2010. A Spatial Analysis of Poverty and Income Inequality in the Appalachian Region. Journal of Rural and Community Development. ISSN: 17128277. 7(2), 118-130. 
Publisher:Rural Development Institute, Brandon University.

Diakses melalui: jrcd.ca/include/getdoc.php?id=1346\&article.

Mehilli, Terida dan Dumi, Alba. 2011. Regional Competitiveness and Development with the Reference to the Situation in Albania. ISSN 2039-2117 Mediterranean Journal of Social Sciences Vol. 2, No. 3, September 2011

Mezei, Zoltan dan Peter, Fodor. Human Resources Development in a Lagging Region. International Journal of Business and Social Science Vol. 3 No. 13; July 2012144.

Mudau, M. J dan Rasila, B. N. 2012. Effective communication as a strategic tool for rural development: A model to take South African Government beyond mobilization and consultation through public participation. Journal of Media and Communication Studies Vol. 4(7), pp. 134-141, November 2012. ISSN 2141-2545 C2012 Academic Journals.

Diakses melalui: www.academicjournals.org/jmcs/PDF/pdf2012/.....

Parson. Wayne. 2008. Public Policy: An Introduction To The Theory and Practice If Policy Analysis. Alih bahasa oleh Tri Wibowo Budi Samtoso. Kencana Pranada Media Group.

Peraturan Pemerintah Nomor 72 Tahun 2005. Tentang Desa.

Peraturan Menteri Negara PDT Nomor: 07/PER/M- PDT/III/2007 tentang Perubahan Keputusan Menteri Negara PDT Nomor 001/KEP/M-PDT/II/2005 tentang Strategi Nasional Pembangunan Daerah Tertinggal

Rasila, B. N dan Mudau, M. J. 2012. Effective communication as a strategic tool for rural development: A model to take South African Government beyond mobilization and consultation through public participation. Journal of Media and Communication Studies Vol. 4(7), pp. 134-141, November 2012. DOI: diakses melalui: http://www.academicjournals.org/jmcs/PDF/

Sitompul,Rislima F. 2009. Merancang Model pengembangan Masyarakat Pedesaan Dengan Pendekatan System Dynamic. LIPI Press. Jakarta.

Suharto, Edi. 2008. kebijakan Sosial Sebagai Kebijakan Publik. Alfabeta, Bandung.

Sumpeno,Wahjudin. 2011. Perencanaan Desa Terpadu. Reinforcement Action and Development

Suryono. Agus. 2010. Dimensi-Dimensi Prima Teori Pembangunan. UB Press.

Uphoff, Norman T dan Esman, Milton J. 1982. Local Organization and Rural Development. RDSCIS, Cornell University Press.

Usman. Suyoto, 2012. Pembangunan Dan Pemberdayaan Masyarakat. Pustaka Pelajar, Yogyakarta.

Undang-Undang Nomor 32 tahun 2004 tentang Pemerintahan Daerah.

Wahab.Solichin A. 2011. Pengantar Analisis Kebijakan Publik. UMM 
Widjaya. HAW. 2006. Otonomi Daerah Dan Otonom Daerah. PT. RajaGrafindo Persada. Jakarta.

Winarno. Budi. 2008. Gagalnya Organisasi Desa Dalam Pembangunan Di Indonesia. Tiara kencana, Yogyakarta.

Yansen, TP.2013. Gerakan Desa Membangun : Sebuah ide Inovatif Tentang Pembangunan Desa.

PT. Danar Wijaya. UB Media. 